\title{
Status gondok berhubungan dengan pola menstruasi dan kejadian anemia pada wanita usia subur di daerah endemik GAKY
}

\author{
Goitre status associated with menstruation pattern and the incidence of anemia in legible women \\ at IDD area
}

Ori Pertami Enardi', Untung S. Widodo², Detty Siti Nurdiati ${ }^{3}$

\begin{abstract}
Background: lodine deficiency disorder (IDD) is one of health problems in Indonesia that has major impact on survival and quality of human resources. lodine is an essential component of thyroid hormone, meanwhile thyroid hormone has an important role in reproductive function. Nutritional anemia is also a nutrition problem in Indonesia. Thyroid hormone deficiency may cause disorder in hemoglobin synthesis due to lack of thyroxine hormone and the incidence of intestine failure to absorb Fe. In hypothyroid condition, the amount of gastric acid secretion will decrease that disrupts absorption of nutrients, including Fe.

Objectives: To identify association between goitre status and menstruation pattern and the incidence of anemia in legible women at IDD endemic area of Kenagarian Siguntur Subdistrict of Sitiung District of Dharmasraya Province of Sumatera Barat.

Methods: The study was observational with cross sectional design that was carried out at Kenagarian Siguntur Subdistrict of Sitiung District of Tanah Datar. Subject of the study were 154 legible women with inclusion criteria 20-40 years old and willing to become respondent and have blood examination. Samples were taken using simple random sampling method. Data analysis used chi square and logistic regression.

Results: The result of data analysis showed that some respondents had goitre (29.9\%), menstruation problem (35.1\%), and were anemic (37.0\%). The result of statistical analysis showed that there was association between goitre status and menstruation pattern (OR: 6.562, 95\% Cl: 3.076-13.99, $p<0.005$ ) and anemia (OR: $3.229,95 \% \mathrm{Cl}: 1.577-6.612, p<0.005)$.

Conclusions: Goitre status had significant association with menstruation pattern and the incidence of anemia.
\end{abstract}

KEYWORDS: iodine deficiency disorder (IDD), menstruation pattern, anemia

\begin{abstract}
ABSTRAK
Latar Belakang: Gangguan akibat kekurangan yodium (GAKY) di Indonesia merupakan salah satu masalah kesehatan. Hal ini disebabkan yodium merupakan komponen penting hormon tiroid, yang juga berperan penting dalam fungsi reproduksi. Defisiensi hormon tiroid dapat mengakibatkan gangguan sintesis hemoglobin dan absorbs besi di usus.

Tujuan: Mengetahui hubungan status gondok dengan pola menstruasi dan kejadian anemia pada wanita usia subur daerah endemik GAKY di Kenagarian Siguntur Kecamatan Sitiung Kabupaten Dharmasraya Propinsi Sumatera Barat.

Metode: Jenis penelitian ini adalah observasional dengan menggunakan rancangan penelitian cross sectional, yang dilakukan di Kenegarian Siguntur Kecamatan Sitiung Kabupaten Tanah Datar. Subjek
\end{abstract}

\footnotetext{
${ }^{1}$ Pasca Sarjana Gizi dan Kesehatan Fakultas Kedokteran Universitas Gadjah Mada, Jl. Farmako, Sekip Utara Yogyakarta 55281, e-mail: ori_letta@yahoo.co.id

2 Balai Penelitian dan Pengembangan Gangguan Akibat Kekurangan lodium (BP2 GAKI) Magelang, Jawa Tengah, 565536

${ }^{3}$ Pasca Sarjana Gizi dan Kesehatan Fakultas Kedokteran Universitas Gadjah Mada, Jl. Farmako, Sekip Utara Yogyakarta 55281
} 
penelitian ini adalah 154 orang wanita usia subur yang dipilih menggunakan metode simple random sampling. Analisis data dilakukan dengan uji chi-square dan regresi logistik.

Hasil: Wanita usia subur yang menderita gondok, mengalami gangguan menstruasi, dan kejadian anemia berturut-turut sebesar 29,9\%,35,1\%, dan 37,0\%. Hasil uji statistik menunjukkan ada hubungan antara status gondok dengan pola menstruasi ( $x^{2}=26,191$, OR: 6,563, 95\% Cl: 3,076-13,99, $\left.p<0,001\right)$ dan anemia $\left(x^{2}=10,708\right.$, OR: 3,229,95\% Cl: 1,577-6,612, $\left.p<0,005\right)$.

Kesimpulan: Status gondok mempunyai hubungan yang signifikan dengan pola menstruasi dan kejadian anemia.

KATA KUNCI: gangguan akibat kekurangan yodium (GAKY), pola menstruasi, anemia

\section{PENDAHULUAN}

Gangguan akibat kekurangan yodium (GAKY) di Indonesia merupakan salah satu masalah kesehatan masyarakat yang serius mengingat dampaknya sangat besar terhadap kelangsungan hidup dan kualitas sumber daya manusia (1). Pada mulanya, defisiensi yodium atau gondok endemik berat dihubungkan dengan hipotiroidisme dan kretin endemik saja. Namun tidak hanya itu, kekurangan yodium juga dapat berpengaruh terhadap perkembangan fisik serta mental manusia sejak dalam kandungan hingga dewasa. GAKY ada yang dapat dilihat dengan jelas dan ada pula yang tidak. Spektrum klinik ini menggambarkan fenomena gunung es yang pada puncaknya yang terlihat adalah gondok dan kretin sedangkan pada bagian bawahnya adalah gangguan reproduksi, gangguan syaraf serta mental dan banyak gangguan lainnya. Sebagian besar gangguan akibat kekurangan yodium ini bersifat irreversibel (2).

Hormon tiroid memainkan peran penting dalam fungsi reproduksi dengan efek melalui ovarium, sex hormone binding globulin (SHBG), faktor koagulasi, dan prolaktin yang dapat berakibat pada terganggunya pola menstruasi. Rendahnya kadar hormon tiroid dapat berakibat pada penurunan SHGB, sehingga estrogen dan progesteron juga berkurang. Selain itu penderita hipotiroid juga berisiko mengalami menoragia akibat gangguan pada fungsi pembekuan darah. Pada hipotiroid juga dapat terjadi peningkatan kadar prolaktin yang menyebabkan hipogonadisme, sehingga jumlah produksi hormon estrogen menurun (3).

Anemia yang sebagian besar disebabkan oleh defisiensi zat besi juga merupakan masalah gizi di Indonesia (4). Pada kondisi hipotiroid, jumlah asam lambung yang disekresi akan mengalami penurunan sehingga dapat mengganggu absorbsi zat-zat gizi termasuk Fe (5). Selain itu, kondisi hipotiroid juga dapat mengakibatkan gangguan sintesis hemoglobin akibat kurangnya hormon tiroksin. Hipotiroid juga mengakibatkan penurunan ketebalan lapisan mukosa dan vili-vili usus halus, pematangan sel epitel dan enzim-enzim di usus halus, sehingga terjadi kegagalan usus untuk mengabsorbsi besi (6).

Berdasarkan uraian di atas perlu dikaji hubungan antara status gondok dengan pola menstruasi serta kejadian anemia pada wanita usia subur (WUS) di daerah endemik GAKY yaitu di Kenagarian Siguntur, Kecamatan Sitiung, Kabupaten Dharmasraya, Provinsi Sumatera Barat.

\section{BAHAN DAN METODE}

Penelitian ini merupakan penelitian observasional dengan rancangan cross sectional. Penelitian dilaksanakan pada bulan Januari hingga Maret 2011. Populasi adalah WUS yang tinggal di daerah endemik GAKY yaitu di Kenagarian Siguntur.

Kriteria inklusi sampel penelitian adalah WUS berusia 20-40 tahun, bersedia menjadi responden, dan melakukan pemeriksaan darah. Kriteria eksklusi adalah memiliki penyakit kelainan reproduksi atau penyakit lain seperti kanker/ kista/ tumor pada rahim atau diabetes melitus dan hipertiroid), mengonsumsi pil KB atau memakai implant dan suntik KB, atau dalam keadaan hamil.

Besar sampel ditentukan menggunakan rumus Lemeshow (7). Sampel sejumlah 154 WUS diambil dengan metode simple random sampling dari populasi semua WUS di Kenagarian Siguntur. 
Variabel bebas adalah status gondok, variabel terikat adalah pola menstruasi dan kejadian anemia. Variabel luar adalah indeks massa tubuh (IMT), aktivitas fisik, lama menstruasi, paritas, umur, umur menarche, dan tingkat pendidikan.

Data status gondok diperoleh berdasarkan indikator klasifikasi gondok menurut WHO, UNICEF \& ICCD yaitu: tidak ada gondok teraba atau terlihat (grade 0), pembesaran kelenjar tiroid tidak terlihat pada posisi normal tetapi teraba oleh palpasi (grade 1) dan pembesaran kelenjar tiroid terlihat dalam kondisi normal (grade 2). Pengukuran palpasi oleh palpator. Data berat badan diperoleh menggunakan timbangan injak dan tinggi badan dengan menggunakan microtoise dengan ketelitian 0,1 $\mathrm{cm}$. Data pola menstruasi diperoleh dari kuesioner dengan melakukan wawancara pada subjek dan pencatatan oleh subjek mengenai siklus menstruasi pada kalender menstruasi (Desember-Januari). Data status anemia diperoleh dari pengambilan sampel darah menggunakan alat pengukur hemoglobin dengan metode hemocue dan dibantu oleh 2 orang laboran. Data aktivitas fisik, paritas, umur, umur menarche, dan tingkat pendidikan diperoleh dengan wawancara menggunakan kuesioner. Penelitian ini dilaksanakan setelah mendapatkan persetujuan dari Komite Etik Universitas Gadjah Mada, dan izin dari Pemerintah Kabupaten Dharmasraya.

Penyajian data dengan analisis univariat untuk mendeskripsikan karakteristik subjek, dan uji chisquare untuk melihat hubungan antarvariabel. Uji regresi logistik digunakan untuk melihat variabel independen yang paling mempengaruhi variabel dependen.

\section{HASIL}

Berdasarkan Tabel 1 dapat dilihat bahwa sebagian besar subjek penelitian memiliki tingkat pendidikan SLTA yaitu sebanyak 110 subjek ( $71,4 \%)$, sebagian berperan sebagai ibu rumah tangga yaitu berjumlah 72 subjek $(46,8 \%)$, dan sebagian besar berstatus menikah, yaitu 93 subjek $(60,4 \%)$. Mayoritas subjek mengalami menstruasi pertama kali yaitu pada umur $\geq 12$ tahun $(88,3 \%)$ dan melakukan aktivitas ringan-sedang $(96,8 \%)$. Subjek berumur $\leq 27$ tahun $(50,6 \%)$ dan paritas $>1(52,6 \%)$ serta sebagian besar memiliki status indeks massa tubuh (IMT) normal (75,33\%).

Tabel 1. Distribusi frekuensi karakteristik responden

\begin{tabular}{|c|c|c|}
\hline Karakteristik & $\begin{array}{l}\text { Frekuensi } \\
(n=154)\end{array}$ & $\begin{array}{c}\text { Persentase } \\
(\%)\end{array}$ \\
\hline \multicolumn{3}{|l|}{ Pendidikan } \\
\hline SD & 7 & 4,5 \\
\hline SLTP & 27 & 17,5 \\
\hline SLTA & 110 & 71,4 \\
\hline Diploma & 5 & 3,2 \\
\hline Sarjana & 5 & 3,2 \\
\hline \multicolumn{3}{|l|}{ Pekerjaan } \\
\hline Tidak bekerja & 34 & 22,1 \\
\hline IRT & 72 & 46,8 \\
\hline Mahasiswi & 16 & 10,4 \\
\hline Wiraswasta & 13 & 8,4 \\
\hline Pegawai swasta & 12 & 7,8 \\
\hline PNS & 7 & 4,6 \\
\hline \multicolumn{3}{|l|}{ Status Menikah } \\
\hline Belum & 58 & 37,7 \\
\hline Menikah & 93 & 60,4 \\
\hline Janda & 3 & 1,9 \\
\hline \multicolumn{3}{|l|}{ Umur } \\
\hline$\leq 27$ tahun & 78 & 50,6 \\
\hline$>27$ tahun & 76 & 49,4 \\
\hline \multicolumn{3}{|l|}{ Paritas } \\
\hline$\leq 1$ kali & 73 & 47,4 \\
\hline$>1$ kali & 81 & 52,6 \\
\hline \multicolumn{3}{|l|}{ IMT } \\
\hline Normal (IMT >18,5-25) & 116 & 75,3 \\
\hline $\begin{array}{l}\text { Tidak normal }(\mathrm{IMT} \leq \\
18,5 \text { atau IMT }>25)\end{array}$ & 38 & 24,7 \\
\hline \multicolumn{3}{|l|}{ Aktivitas fisik } \\
\hline Ada & 149 & 96,8 \\
\hline Tidak & 5 & 3,2 \\
\hline \multicolumn{3}{|l|}{ Umur menarche } \\
\hline$\geq 12$ tahun & 136 & 88,3 \\
\hline$<12$ tahun & 18 & 11,7 \\
\hline
\end{tabular}

Berdasarkan Tabel 2 dapat dilihat bahwa hasil pemeriksaan palpasi pada 154 subjek sebanyak $46(29,9 \%)$ mengalami pembesaran kelenjar tiroid (gondok). Berdasarkan indikator gangguan siklus, lama, dan banyak darah menstruasi dapat dilihat terdapat cukup banyak gangguan menstruasi yaitu sebesar $54(35,1 \%)$ dari 154 subjek. Sementara itu, berdasarkan hasil pengukuran kadar hemoglobin $(\mathrm{Hb})$ dengan menggunakan metode hemocue diperoleh sebagian besar subjek dengan kadar hemoglobin $<12$ $\mathrm{mg} / \mathrm{dL}$ (anemia) berjumlah 57 (37,0\%). 
Tabel 2. Status gondok, anemia, dan pola menstruasi

\begin{tabular}{|c|c|c|}
\hline Status & $\begin{array}{c}\text { Frekuensi } \\
(n=154)\end{array}$ & $\begin{array}{c}\text { Persentase } \\
(\%)\end{array}$ \\
\hline \multicolumn{3}{|l|}{ Status gondok } \\
\hline Tidak gondok & 108 & 70,1 \\
\hline Gondok & 46 & 29,9 \\
\hline \multicolumn{3}{|l|}{ Status anemia } \\
\hline Normal (Hb: $\geq 12 \mathrm{mg} / \mathrm{dL})$ & 97 & 63,0 \\
\hline Anemia (Hb: <12 mg/dL) & 57 & 37,0 \\
\hline \multicolumn{3}{|l|}{ Siklus menstruasi } \\
\hline Normal (21-35 hari) & 127 & 82,2 \\
\hline Polimenorea (<21 hari) & 3 & 1,9 \\
\hline Oligomenorea (>35 hari) & 15 & 9,7 \\
\hline Metroragia/ tidak teratur & 9 & 5,8 \\
\hline \multicolumn{3}{|l|}{ Lama menstruasi } \\
\hline Normal (2-5 hari) & 121 & 76,6 \\
\hline Menoragia (>5 hari) & 33 & 21,4 \\
\hline \multicolumn{3}{|l|}{ Banyak darah } \\
\hline Normal (2-5 pads/hari) & 147 & 95,5 \\
\hline $\begin{array}{l}\text { Hipomenorea (<2 pads / } \\
\text { hari) }\end{array}$ & 7 & 4,5 \\
\hline \multicolumn{3}{|l|}{ Gangguan menstruasi } \\
\hline Tidak ada & 100 & 64,9 \\
\hline Ada gangguan & 54 & 35,1 \\
\hline
\end{tabular}

Tabel 3 menunjukkan bahwa sebanyak $15,2 \%$ penderita gondok memiliki pola menstruasi (siklus menstruasi, lama menstruasi, dan banyak darah) oligomeorea, sedangkan yang memiliki pola metroragia, menoragia, dan hipomenorea, berturutturut sebanyak $13 \% ; 52,2 \%$; dan $2,2 \%$. Oleh karena itu, berdasarkan kategori adanya gangguan pola menstruasi pada penderita gondok, sebanyak $65,2 \%$ mengalami gangguan menstruasi, sedangkan anemia sebanyak $56,5 \%$ dialami oleh penderita gondok.

Tabel 4 menunjukkan adanya hubungan yang signifikan antara status gondok dengan gangguan pola menstruasi $(p<0,05)$. Sementara itu, odds ratio (OR) sebesar 6 menunjukkan bahwa penderita gondok memiliki peluang 6 kali lebih besar mengalami gangguan menstruasi dibanding yang tidak mengalami gondok.

Tabel 5 menunjukkan tidak terdapat hubungan yang signifikan antara IMT, aktivitas fisik, umur, dan umur menarche dengan gangguan pola menstruasi yang didapatkan nilai $p>0,05$.

Tabel 6 menunjukkan bahwa ada hubungan yang signifikan antara status gondok dengan kejadian anemia yang ditunjukkan nilai $p<0,05$. Sementara itu, OR sebesar 3 menunjukkan bahwa penderita gondok memiliki peluang 3 kali lebih besar mengalami anemia dibanding yang tidak mengalami gondok.

Pada Tabel 7 menunjukkan ada hubungan yang signifikan antara lama menstruasi dengan

Tabel 3. Distribusi frekuensi pola menstruasi dan status anemia berdasarkan status gondok

\begin{tabular}{|c|c|c|c|c|}
\hline \multirow[t]{3}{*}{ Pola menstruasi } & \multicolumn{4}{|c|}{ Status gondok } \\
\hline & \multicolumn{2}{|c|}{ Tidak gondok } & \multicolumn{2}{|c|}{ Gondok } \\
\hline & $\mathbf{n}$ & $\%$ & $\mathbf{n}$ & $\%$ \\
\hline \multicolumn{5}{|l|}{ Siklus menstruasi } \\
\hline Normal (21-35 hari) & 96 & 88,9 & 31 & 67,4 \\
\hline Polimenorea (<21 hari) & 1 & 0,9 & 2 & 4,3 \\
\hline Oligomenorea (>35 hari) & 8 & 7,4 & 7 & 15.2 \\
\hline Tidak teratur/metroragia & 3 & 2,8 & 6 & 13,0 \\
\hline \multicolumn{5}{|l|}{ Lama menstruasi } \\
\hline Normal (2-5 hari) & 98 & 90,7 & 22 & 47,8 \\
\hline Menoragia (>5 hari) & 10 & 9,3 & 23 & 52.2 \\
\hline Brakimenorea $(<2$ hari) & 0 & 0,0 & 0 & 0,0 \\
\hline \multicolumn{5}{|l|}{ Banyak darah } \\
\hline Normal (2-5 pads/hari) & 102 & 94,4 & 45 & 97,8 \\
\hline Hipermonorea (>5 pads/ hari) & 0 & 0,0 & 0 & 0,0 \\
\hline Hipomenorea (<2 pads /hari) & 6 & 5,6 & 1 & 2,2 \\
\hline \multicolumn{5}{|l|}{ Gangguan menstruasi } \\
\hline Tidak ada gangguan & 84 & 77,8 & 16 & 34,8 \\
\hline Ada gangguan & 24 & 22,2 & 30 & 65,2 \\
\hline \multicolumn{5}{|l|}{ Status anemia } \\
\hline Normal $\geq 12 \mathrm{mg} / \mathrm{dL}$ & 77 & 71,3 & 20 & 43,5 \\
\hline Anemia $<12 \mathrm{mg} / \mathrm{dL}$ & 31 & 28,7 & 26 & 56,5 \\
\hline
\end{tabular}


Tabel 4. Hubungan status gondok dengan pola menstruasi

\begin{tabular}{|c|c|c|c|c|}
\hline \multirow[b]{2}{*}{$\begin{array}{l}\text { Status } \\
\text { gondok }\end{array}$} & \multicolumn{2}{|c|}{ Gangguan pola menstruasi $(n=154)$} & \multirow[b]{2}{*}{ OR } & \multirow[b]{2}{*}{$95 \% \mathrm{Cl}$} \\
\hline & $\begin{array}{c}\text { Tidak ada } \\
\mathrm{n}(\%)\end{array}$ & $\begin{array}{l}\text { Ada } \\
\mathrm{n}(\%)\end{array}$ & & \\
\hline Tidak gondok & $84(77,8 \%)$ & $24(22,2 \%)$ & & \\
\hline Gondok & $16(34,8 \%)$ & $30(65,2 \%)$ & & \\
\hline
\end{tabular}

Tabel 5. Hubungan faktor risiko dengan pola menstruasi

\begin{tabular}{|c|c|c|c|c|}
\hline \multirow{2}{*}{ Faktor risiko } & \multicolumn{2}{|c|}{$\begin{array}{l}\text { Gangguan pola menstruasi } \\
\qquad(n=154)\end{array}$} & \multirow{2}{*}{ OR } & \multirow{2}{*}{$95 \% \mathrm{Cl}$} \\
\hline & $\begin{array}{l}\text { Tidak ada } \\
\text { n(\%) }\end{array}$ & $\begin{array}{l}\text { Ada } \\
\text { n(\%) }\end{array}$ & & \\
\hline \multicolumn{5}{|l|}{ IMT } \\
\hline Normal (IMT >18,5-25) & $79(66,9 \%)$ & $39(33,1 \%)$ & \multirow{2}{*}{1,447} & \multirow[t]{2}{*}{$0,673-3,111$} \\
\hline Tidak normal $(\mathrm{IMT} \leq 18,5$ atau $\mathrm{IMT}>25)$ & $21(58,3 \%)$ & $15(41,7 \%)$ & & \\
\hline \multicolumn{5}{|l|}{ Aktivitas fisik } \\
\hline Ringan/sedang & $97(65,1 \%)$ & $52(34,9 \%)$ & \multirow[t]{2}{*}{1,244} & \multirow[t]{2}{*}{$0,201-7,680$} \\
\hline Berat & $3(60,0 \%)$ & $2(40,0 \%)$ & & \\
\hline \multicolumn{5}{|l|}{ Umur } \\
\hline$\leq 27$ tahun & $53(67,9 \%)$ & $25(32,1 \%)$ & \multirow[t]{2}{*}{1,308} & \multirow[t]{2}{*}{$0,674-2,540$} \\
\hline$>27$ tahun & $47(61,8 \%)$ & $29(38,2 \%)$ & & \\
\hline \multicolumn{5}{|l|}{ Umur menarche } \\
\hline$\geq 12$ tahun & $85(62,5 \%)$ & $51(37,5 \%)$ & \multirow[t]{2}{*}{0,333} & \multirow[t]{2}{*}{$0,092-1,208$} \\
\hline$<12$ tahun & $15(83,3 \%)$ & $3(16,7 \%)$ & & \\
\hline
\end{tabular}

Tabel 6. Hubungan status gondok dengan kejadian anemia

\begin{tabular}{lcccc}
\hline Status gondok & \multicolumn{2}{c}{ Kejadian anemia $(\mathbf{n = 1 5 4 )}$} & \multirow{2}{*}{ OR } & \multirow{2}{*}{$\mathbf{9 5 \%} \mathbf{~ C l}$} \\
\cline { 2 - 3 } & $\begin{array}{c}\text { Normal } \\
\mathbf{n}(\%)\end{array}$ & $\begin{array}{c}\text { Anemia } \\
\mathbf{n}(\%)\end{array}$ & & \\
\hline Tidak gondok & $\begin{array}{c}77(50,0 \%) \\
\text { Gondok }\end{array}$ & $\begin{array}{c}31(20,1 \%) \\
20(13,0 \%)\end{array}$ & 26,229 & $1,577-6,612$ \\
\hline
\end{tabular}

kejadian anemia yang ditunjukkan oleh nilai $p<0,05$. Sementara itu, OR sebesar 3,2 menunjukkan bahwa wanita dengan menoragia memiliki peluang 3,2 kali lebih besar mengalami anemia dibanding yang tidak mengalami menoragia (normal). Sebaliknya, variabel paritas, IMT, dan tingkat pendidikan tidak berhubungan ( $p>0,05)$.

Berdasarkan hasil multivariat pada Tabel 8 didapatkan bahwa variabel yang berhubungan signifikan dengan pola menstruasi adalah variabel status gondok, sedangkan variabel umur menarche, IMT, aktivitas fisik, dan umur tidak berhubungan. Hasil analisis didapatkan OR sebesar 6,562 (95\% $\mathrm{Cl}=3,076-13,999)$ yang berarti WUS yang gondok mempunyai peluang 6 kali mengalami gangguan menstruasi dibandingkan WUS yang tidak gondok setelah dikontrol variabel umur menarche, IMT, aktivitas fisik, dan umur. Dalam data penelitian ini, variabel yang paling berpengaruh terhadap pola menstruasi adalah status gondok.

Dari hasil akhir analisis multivariat dapat dilihat variabel yang berhubungan signifikan terhadap kejadian anemia adalah variabel status gondok dengan nilai OR 3,229, sedangkan variabel lama menstruasi dan tingkat pendidikan tidak berhubungan. WUS yang gondok mempunyai peluang 3 kali mengalami anemia dibandingkan WUS yang tidak gondok setelah dikontrol variabel IMT, paritas, lama menstruasi dan tingkat pendidikan. Dalam data penelitian ini variabel yang paling berpengaruh terhadap kejadian anemia adalah status gondok. 
Tabel 7. Hubungan faktor risiko dengan kejadian anemia pada wanita usia subur (WUS) daerah endemik GAKY

\begin{tabular}{|c|c|c|c|c|}
\hline \multirow[b]{2}{*}{ Faktor risiko } & \multicolumn{2}{|c|}{ Kejadian anemia $(n=154)$} & \multirow[b]{2}{*}{ OR } & \multirow[b]{2}{*}{$95 \% \mathrm{Cl}$} \\
\hline & $\begin{array}{c}\text { Normal } \\
\mathrm{n}(\%)\end{array}$ & $\begin{array}{c}\text { Anemia } \\
\mathrm{n}(\%)\end{array}$ & & \\
\hline \multicolumn{5}{|l|}{ Lama menstruasi } \\
\hline Normal (2-5 hari) & $83(53,9 \%)$ & $37(24,0 \%)$ & 3,205 & $1,461-7,027$ \\
\hline Menoragia (>5 hari) & $14(9,1 \%)$ & $20(13,0 \%)$ & & \\
\hline \multicolumn{5}{|l|}{ Paritas } \\
\hline$\leq 1$ & $48(31,2 \%)$ & $25(16,2 \%)$ & 1,254 & $0,650-2,420$ \\
\hline$>1$ & $49(31,8 \%)$ & $32(20,8 \%)$ & & \\
\hline \multicolumn{5}{|l|}{ IMT } \\
\hline Normal/lebih $($ IMT >18,5) & $86(62,3 \%)$ & $52(37,7 \%)$ & 0,752 & $0,274-2,285$ \\
\hline Kurang (IMT $\leq 18,5)$ & $11(68,8 \%)$ & $5(31,3 \%)$ & & \\
\hline \multicolumn{5}{|l|}{ Tingkat pendidikan } \\
\hline Rendah (tamat <SLTP) & $18(52,9, \%)$ & $16(47,1 \%)$ & 0,584 & $0,270-1,263$ \\
\hline Tinggi (tamat $\geq S L T A$ ) & $79(65,8 \%)$ & $12(34,2 \%)$ & & \\
\hline
\end{tabular}

Tabel 8. Hasil analisis multivariat regresi logistik antara status gondok, IMT, aktivitas fisik, umur menarche, dan umur dengan pola menstruasi

\begin{tabular}{llc}
\hline & \multicolumn{1}{c}{ Variabel } & OR (95\% CI) \\
\cline { 2 - 3 } Step 1 & Status Gondok & $6,269(2,761-14,236)$ \\
& IMT & $0,759(0,341-1,689)$ \\
& Aktivitas fisik & $2,102(0,270-16,398)$ \\
& Umur menarche & $0,661(0,166-2,630)$ \\
& Umur & $0,873(0,403-1,890)$ \\
Step 2 & Status gondok & $6,017(2,750-13,162)$ \\
& IMT & $0,741(0,337-1,630)$ \\
& Aktivitas fisik & $2,074(0,265-16,229)$ \\
& Umur menarche & $0,661(0,167-2,260)$ \\
Step 3 & Status gondok & $6,355(2,956-13,658)$ \\
& IMT & $0,715(0,329-1,558)$ \\
& Umur menarche & $1,871(0,252-13,895)$ \\
Step 4 & Status gondok & $6,298(2,936-13,511)$ \\
& IMT & $0,742(0,344-1,599)$ \\
Step 5 & Status gondok & $6,562(3,076-13,999)$ \\
\hline
\end{tabular}

\section{BAHASAN}

Hubungan status gondok dan faktor risiko lain (IMT, aktivitas fisik, umur responden, dan umur menarche) dengan gangguan menstruasi pada WUS di daerah endemik GAKY

Hipotiroid pada wanita sering dikaitkan dengan kelainan menstruasi. Hipotiroid berhubungan dengan gangguan reproduksi seperti menstruasi tidak teratur dan gangguan menstruasi lainnya, keguguran spontan sampai infertilitas. Pada WUS hipotiroid menyebabkan perubahan dan jumlah darah seperti oligomenorea, amenorea, polimenorea, dan menoragia (8).
Tabel 9. Hasil analisis multivariat regresi logistik antara status gondok, IMT, paritas, lama menstruasi, tingkat pendidikan dengan kejadian anemia

\begin{tabular}{lll}
\hline & \multicolumn{1}{c}{ Variabel } & OR $(\mathbf{9 5} \% \mathrm{Cl})$ \\
\cline { 2 - 3 } Step 1 & Status Gondok & $2,206(0,941-5,171)$ \\
& IMT & $0,912(0,391-2,128)$ \\
& Paritas & $1,115(0,530-2,346)$ \\
& Tingkat pendidikan & $0,846(0,347-2,064)$ \\
Step 2 & Lama menstruasi & $2,141(0,865-5,301)$ \\
& Status gondok & $2,250(0,978-5,174)$ \\
& Paritas & $1,120(0,533-2,354)$ \\
& Tingkat pendidikan & $0,860(0,358-2,069)$ \\
Step 3 & Lama menstruasi & $2,125(0,861-5,245)$ \\
& Status gondok & $2,298(1,011-5,227)$ \\
& Tingkat pendidikan & $0,826(0,358-1,907)$ \\
Step 4 & Lama menstruasi & $2,069(0,854-5,014)$ \\
& Status gondok & $2,394(1,073-5,340)$ \\
Step 5 & Lama menstruasi & $2,088(0,863-5,053)$ \\
& Status gondok & $3,229(1,577-6,612)$ \\
\hline
\end{tabular}

Hipotiroid timbul karena kurangnya produksi hormon tiroid yang manifestasinya dapat melibatkan beberapa sistem hormon, termasuk sistem reproduksi. Pola menstruasi dipengaruhi oleh hormon tiroid secara langsung melalui dampak pada ovarium dan tidak langsung melalui dampaknya terhadap SHBG, prolaktin (PRL), dan faktor koagulasi. Hipotiroid menyebabkan perubahan prekursor estrogen menjadi estrogen, menyebabkan perubahan sekresi FSH, Luteinizing Hormone (LH) sehingga terjadi gangguan menstruasi (3). Gangguan menstruasi mempunyai mekanisme 
yang berbeda diantaranya perubahan respon $\mathrm{TRH}$, $\mathrm{LH}$, dan perubahan androgen menjadi estrogen, perubahan pada metabolisme androstendione dan perubahan level SHBG (9).

Hasil penelitian ini sesuai dengan hasil penelitian di Ethiopia tahun 2005 yang menunjukkan bahwa $16,7 \%$ wanita gondok mempunyai riwayat satu atau lebih gangguan reproduksi. Secara statistik, terdapat hubungan antara kejadian gondok dengan gangguan reproduksi. Gangguan reproduksi juga lebih banyak ditemukan pada daerah endemisitas tinggi dan secara statistik lebih signifikan dibandingkan dengan daerah endemisitas rendah (10). Penelitian yang lain menemukan prevalensi sebesar $23,4 \%$ atau 40 dari 171 pasien hipotiroid mengalami gangguan menstruasi (11).

Gangguan tiroid berhubungan dengan gangguan menstruasi. Gangguan menstruasi yang terbanyak adalah menoragia yaitu sebanyak $40 \%$. Sesuai dengan hasil penelitian ini, $52,2 \%$ wanita gondok mengalami menoragia (12). Menoragia dan polimenorea pada hipotiroid diduga disebabkan oleh gangguan homeostatis (peristiwa penghentian darah karena pembuluh darah putus atau robek) seperti penurunan faktor VII, VIII, IX, dan XI, yang merupakan faktor penentu dalam proses pembekuan darah (koagulasi) (8).

Pada kelompok hipotiroid, terjadi gangguan menstruasi seperti menoragia (50\%) dan metroragia $(30 \%)$. Selain itu, pada keadaan hipotiroid terjadi gangguan menstruasi seperti menstruasi tidak teratur dengan berubahnya panjang siklus dan jumlah darah yang keluar (13).

Berdasarkan analisis statistic, variabel luar yaitu IMT, aktivitas fisik, umur, dan umur menarche tidak berhubungan dengan pola menstruasi. Pada penelitian lain juga didapatkan hasil tidak ada hubungan yang kuat antara siklus menstruasi dengan IMT serta tidak ada pengaruh yang signifikan antara aktivitas fisik terhadap siklus menstruasi

Penelitian lain yang dilakukan terhadap 580 subjek menunjukkan bahwa terdapat hubungan yang positif antara IMT dengan siklus menstruasi teratur (15). Perbedaan hasil ini dikarenakan jumlah sampel pada penelitian ini hanya 154 subjek dimana dari hasil perhitungan dan kategori IMT tidak terlalu bervariasi, karena lebih dari setengah dari subjek memiliki IMT yang normal. Sedangkan aktivitas fisik yang dapat mempengaruhi pola menstruasi adalah aktivitas yang berat seperti atlet, sedangkan subjek mayoritas mempunyai aktivitas ringan dan sedang. Begitu juga dengan umur menarche tidak berhubungan dengan pola menstruasi dikarenakan umur menarche lebih berhubungan dengan pola menstruasi pada remaja, sedangkan pada penelitian ini subjek yang dipilih adalah wanita umur 20-40 tahun.

\section{Hubungan status gondok dan faktor resiko lain (lama menstruasi, paritas, IMT dan tingkat pendidikan) dengan kejadian anemia pada WUS di daerah endemik GAKY}

Hasil analisis hubungan status gondok dengan kejadian anemia di daerah penelitian menunjukkan adanya hubungan signifikan antara status gondok dengan kejadian anemia. Berdasarkan penelitian ini menemukan bahwa di daerah endemik GAKY prevalensi anemia cukup tinggi pada wanita yang cenderung defisiensi yodium (gondok). Sesuai dengan penelitian sebelumnya yang menunjukkan bahwa dari hasil pengukuran hemoglobin pada kasus hipotiroid terjadi penurunan kadar hemoglobin dengan rata-rata $10,96 \mathrm{~g} / \mathrm{dL}$ dan secara statistik terdapat hubungan yang signifikan (12).

Penelitian lain di Kota Palu Sulawesi Tengah juga menunjukkan bahwa terdapat hubungan yang signifikan antara anemia dengan status gondok dengan nilai Odds Ratio (OR=2,933) (15). Hasil penelitian ini berbeda dengan hasil penelitian yang menyatakan tidak ada hubungan antara status anemia dengan status GAKY pada anak sekolah dasar, di Kabupaten Dairi Sumatera Utara (16) dan pada ibu hamil di Tabunganen Barito Kuala, Kalimantan Selatan (17).

Perbedaan dengan hasil penelitian ini karena subjek penelitian yang digunakan berbeda. Pada penelitian tersebut subjeknya adalah anak sekolah dasar dimana mereka sebagian besar belum mengalami menstruasi sedangkan penelitian ini subjeknya adalah wanita usia subur. Dari hasil penelitian ini terjadinya anemia diduga salah satunya karena berhubungan dengan lama menstruasi (menoragia). Penelitian yang dilakukan di India pada 
remaja menunjukkan angka kejadian anemia sebesar $59,8 \%$ dari 630 subjek. Keadaan ini dipengaruhi berbagai faktor risiko, salah satunya adalah lamanya perdarahan pada saat menstruasi (18).

Defisiensi zat besi (Fe) akan menurunkan aktivitas enzim Tiroid Peroxidase (TPO). TPO merupakan enzim yang mengandung heme yang mengkatalis dua langkah penting dalam sintesis hormon tiroid, yaitu proses organifikasi dan coupling $(19,20)$. Penelitian di Pantai Gading juga menunjukkan bahwa suplementasi zat besi dapat meningkatkan keberhasilan penggunaan garam beryodium pada anak yang menderita gondok dan defisiensi zat besi (21).

Sedangkan faktor risiko yang lain (paritas, IMT dan tingkat pendidikan) berdasarkan hasil analisis statistik tidak berhubungan dengan kejadian anemia. Hasil penelitian ini didukung hasil penelitian pada wanita Meksiko Amerika yang menunjukkan tidak ada hubungan antara umur, tingkat pendidikan dan paritas dengan anemia $(22,23)$. Penelitian di India juga menunjukkan bahwa tidak ada hubungan yang signifikan antara pendidikan, status sosial ekonomi dengan anemia, tetapi ditemukan hubungan yang signifikan antara kelebihan perdarahan pada saat menstruasi dengan anemia $(\mathrm{OR}=5,65)(19)$.

Sejalan dengan hasil penelitian di Meksiko yang menunjukkan bahwa tingkat pendidikan tidak berpengaruh signifikan terhadap penyediaan makanan dengan asupan zat gizi yang cukup di rumah tangga (24). Penelitian lain di India juga menemukan bahwa kejadian anemia tidak berhubungan dengan indeks massa tubuh (25).

Penelitian ini juga menunjukkan bahwa status gizi wanita usia subur tidak berhubungan dengan kejadian anemia. Hasil penelitian ini berbeda dengan penelitian di Tamilnadu yang menyatakan bahwa status gizi berpengaruh terhadap kejadian anemia. Hasil ini berbeda dimungkinkan disebabkan karena status gizi subjek pada penelitian ini rata-rata tergolong normal (26).

\section{KESIMPULAN DAN SARAN}

Berdasarkan hasil penelitian dan pembahasan dapat ditarik kesimpulan bahwa terdapat hubungan yang signifikan antara status gondok dengan pola menstruasi dan kejadian anemia pada WUS daerah endemik GAKY di Kenagarian Siguntur, Kecamatan Sitiung, Kabupaten Dharmasraya, Sumatera Barat.

Petugas kesehatan sebagai perpanjangan tangan pemerintah di lokasi penelitian diharapkan dapat memberikan penyuluhan dan informasi kepada masyarakat agar lebih memahami dan menyadari arti penting asupan gizi yang seimbang sehingga kebutuhan zat gizi mikro terutama yodium dan Fe dapat dipenuhi. Serta dalam rangka program perbaikan gizi sebaiknya untuk wanita usia subur tidak diberi yodium saja tetapi juga diberikan suplementasi Fe.

\section{RUJUKAN}

1. Depkes RI. Rencana Aksi Nasional Kesinambungan Program Penanggulangan Gangguan Akibat Kekurangan Yodium. Jakarta: Tim Penanggulangan GAKY Pusat. 2005.

2. Djokomoeljanto, R. Spektrum Klinik Gangguan Akibat Kekurangan Yodium: Dari Gondok Hingga Kretin Endemik. Jurnal GAKY Indonesial. 2002;3(1):1-5.

3. Poppe, K., Velkeiners, B. \& Glinoert, D. Thyroid Disease and Female Reproduction: Clinical Endocrinology. United Kingdom: Blackwell Publishing; 2007.

4. Almatsier, S. Prinsip Dasar IImu Gizi. Jakarta: PT. Gramedia Pustaka Utama; 2001.

5. Rafsanjani, F. N., Saleh Z., Mohammad K. G. Naseri, dan Vahedian, J. EfFect of Thyroid Hormones on Distensioninduced Gastric Acid and Pepsin Secretions In Rats. Annals of Saudi Medicine. 2002;22(5-6):308-11.

6. Greenpan, Francis S., Cooper, D.S.\& Ladenson, P.W. The Thyroid Gland. Dalam: Greenspan's Basic \& Clinical Enocrinology. Eighth Edition. New York : McGraw Hill Medical; 2004.

7. Lemeshow, S., David W Hosmer Jr., Jannele Klar, Stephen K. Lwanga. Adequasy of Sample Size in Health Studies. England : John Wiley and Son Ltd;1997

8. Krassas, G.E. The Male and Female Reproductive System in Hypothyroidsm. dalam 
Werner \& Ingbar. The Thyroid. A Fundamental and Clinical Text. Ninth Edition. Philadelphia : J.B. Lippinscott Company Editor Lewis E.B. \& Robert, D.U; 2005.

9. Colon, J.M., M.R. Peyser, J.B. Lessing, M. Ganguly, C. Yavetz and G. Weiss. The EfFect of Thyrotropin Releasing Hormone Stimulation on Serum Level of Gonadotropins in Women During The Folicular and Luteal Phases of The Menstrual Cycle. Feril Steril. 1998;49:809-12.

10. Abuye, C. \& Barhane, Y. The goitre Rate, Its Association with Reproductive Failure, and The Knowledge of lodine Disorders (IDD) among Women in Ethiopia: Cross-section Community Based Study. BMC Public Health. 2007;7 (316);1471-2458.

11. Krassas, G.E., Pontikides, N., Kaltsas, T., Papadopoulou, Paunkovic J., Paunkovic, N. \& Duntas, L. Disturbances of Menstruation in Hypothyroidsm. Clinical Endocrinology: Blackwell Science. 1999;50;655-659.

12. Sirichand, P. Devrajani, B., Abbasi, R., Shah, S., Devrajani, T. \& Bibi, I. Impaired Thyroid Function in Patients with Menstrual Disturbances. World Applied Sciences Journal. 2009;7(4);538-42.

13. El-Ebrashi, I.N., Ramzy, A.I. \& Al-Kholy, B.M. Asessment of Thyroid Function in Patients with Menstrual Irregulaties. Science Medical Journal ESCME. 1999;11(4); 27- 31.

14. Van Hoff, M.A.H., Voorhorst, F.J., Kaptein, M.B.H.,Hirasing, R.A., Koppenaal, C., Schoemaker. Relationship of the Menstrual Cycle Pattern in 14-17 years old adolescent with Gynaecological Age, Body Mass Index and historical parameters. Human Reproduction. 1998;13(8); 2252-60

15. Jarvelaid, Mari. The efFect of gynecology age, body mass index and psychososial environtment on menstrual regularity among teenaged Females. Acta Obstet Gynecol Scand. 2005;84:645-9

16. Patuti, N., Sudargo, T. \& Nurwachid, D. Faktorfaktor yang Berhubungan dengan kejadian GAKI pada anak sekolah dasar di pinggiran pantai Kota Palu Provinsi Sulawasi Tengah. Jurnal Gizi Klinik Indonesia. 2010;7(1):17-26.
17. Alfitri, Widodo, U.S., Sudargo, T. Faktor-faktor pada kejadian GAKY Ibu Hamil di Tabunganen Barito Kuala, Kalimantan Selatan. Jurnal Gizi dan Dietetik Indonesia. 2013; 1(1): 7-14.

18. Sihite, G., Sudargo, T. \& Adiyanti, M.G. Hubungan antara Status Gangguan Akibat Kekurangan Yodium (GAKI), status anemia dengan prestasi belajar anak SD di Kabupaten Dairi Sumatera Utara. Jurnal Gizi Klinik Indonesia. 2008;4(3);125-32.

19. Kaur, S., Desmurkh, P. R. \& Garg, B.S. Epidemiological Correlates of Nutritional Anemia inAdolescent Girls Of Rural Wardha. Indian Journal of Community Medicine..2006;31:255-6.

20. Hess, S.Y., Michael B., Zimimmerman, Myrtha Arnorld, Wolfgang L., Richard F.H. Iron Deficiency Anemia Reduce Thyroid Peroxidase Activity in Rats. The American Society of Nutritional Sciences. Journal Nutrition. 2002;137:1951-55.

21. Gropper, S.S., Smith, J.L. \& Groff, J.L. Advanced Nutrition and Human Metabolism. Fourth Edition. USA : Thomson Wardsworth; 2005.

22. Zimmerman, M.B.,Adou, P., Zeder, C., Torresani T. and Hurrel R.F. Persistence of Goiter Despite Oral lodine Supplementation in Goitrous Children with Iron DeFeciency Anemia in The Cote d'Ivore. American Journal Clinical Nutrition. 2000;71:88-93.

23. Terhune, A.L.F, Mary E.C. Laura, K.K., Julie, C.W \& Usha, R. Iron deficiency anemia: higher prevalence in Mexican American than in nonHispanic white Females in the third National Health and Nutritional Examintion Survey, 19881994. The American Journal Clinical Nutrition. 2000;72:963-8

24. Backstrasnd, J.F., Allen, L.H., Black, A.K., De Mata, M., Pelto, G.H. Diet and iron status of non pregnant women in rural Central Mexico. The American Journal Nutrition. 2001; 76:156-64

25. Shah, J. \& Gupta, M. Anemia in Adolescent girls: A preliminary report from semi-urban Nepal. Indian Pediatr. 2002;39:1126-30

26. Rajaratnam, J., Abel, R., Asokan, J.S. Jonathan, P. Prevalence of Anemia Among Adolescent Girls of Rural Tamilnadu. Indian Pediatric. 2000;37:532-6 